\title{
SOBRE OMBROS DE GIGANTES
}

Sir Isaac Newton popularizou a metáfora atribuída a Bernard de Chartres, no século XII: "Se vi mais longe foi por estar de pé sobre ombros de gigantes", simbolizando que não produzimos mais avanços por sermos mais brilhantes do que outros, mas por nos apoiarmos no conhecimento já estabelecido. Na semana em que escrevo este editorial, acontecem as reuniões do Alloy Phase International Commission (APDIC) e do XLIV CALPHAD, onde se buscam a troca de experiências e o aprendizado junto ao trabalho desenvolvido por outros importantes grupos, possibilitando, assim, um avanço muito mais rápido e significativo, se comparado ao obtido por cada um de nós, isoladamente, em suas respectivas áreas.

Este ano, a ABM decidiu modificar o modelo de seus eventos, de modo a intensificar, ainda mais, a interação entre diferentes grupos, proporcionando a sinergia entre trabalhos paralelos, em temas não exatamente iguais, porém com grandes chances para que novas ideias, inovações e aplicações possam surgir de forma mais rápida e eficaz do que em encontros monotemáticos.

No ano do $70^{\circ}$ Congresso Anual, a ABM apresenta a ABM WEEK 20I5, semana em que, além do próprio Congresso, ocorrerão também os tradicionais Seminários de Redução, Minério de Ferro e Aglomeração, Aciaria, Laminação, Automação \& TI, Trefilação, Balanços Energéticos e Gases Industriais, Logística, Encontro de Estudantes, o ENEMET e, em parceria com a Abinox, o Seminário Brasileiro de Aço Inoxidável. Ao mesmo tempo, reuniões plenárias sobre materiais para a indústria automobilística, petróleo, uso de recursos hídricos na mineração e mecanismos de inovação completarão a agenda. Contamos com 864 trabalhos inscritos, oriundos de 16 países, indicando grande aceitação do público ao evento. Entre os vários palestrantes convidados, estão o Prof. John Speer, do Colorado School of Mines, ganhador do Hume-Rothery Award, e o Prof. Hansoo Lee, da POSTECH, que recentemente desenvolveu um aço bastante revolucionário.

Eventos integrados como a ABM WEEK podem trazer uma grande sinergia para o desenvolvimento do nosso setor, colocando em contato todas as áreas do processamento - desde a mineração até a utilização dos materiais. Em geral, nossos seminários e congressos têm sido mais na linha de "preaching to the choir", em que especialistas falam para audiências interessadas em temas específicos. Este modelo tem sido bem-sucedido, promovendo desenvolvimento dentro de cada área de interesse. Entretanto, o desafio que a ABM se coloca, agora, é tentar estabelecer maior comunicação entre as várias áreas e setores, de modo a conjuntamente acelerar o desenvolvimento e derrubar barreiras. Este é mais um obstáculo que a associação se propôs a superar: alterar um antigo paradigma para proporcionar mudanças que objetivam beneficiar toda a cadeia produtiva.

Cabe a todos nós, organizadores e participantes do evento, saírmos por um momento das nossas "caixas", instigando a curiosidade a visitar outros temas e expandir o alcance de nossas visões para, quem sabe, nos dar a oportunidade de novos insights, ainda mais abrangentes.

André Luiz Vasconcellos da Costa e Silva Editor-chefe 